\title{
KETAHANAN HIDUP PASIEN KANKER SERVIKS BERDASARKAN STADIUM KANKER
}

\author{
Zubaidah', Rico Januar Sitorus' ${ }^{2}$, Rostika Flora ${ }^{3}$ \\ 'Program Magister IImu Kesehatan Masyarakat Fakultas Kesehatan Masyarakat Universitas Sriwijaya, RSUP. \\ Dr. Mohammad Hoesin Palembang ${ }^{2}$ Fakultas Kesehatan Masyarakat Universitas Sriwijaya, ${ }^{3}$ Fakultas \\ Kesehatan Masyarakat Universitas Sriwijaya \\ Email : 'ucu_zubaidah@yahoo.com, ${ }^{2}$ ciocianathan@gmail.com, 3rostikaflora@gmail.com
}

\begin{abstract}
Background : Cervical cancer is the most common malignancy of the reproductive system and causes many deaths in women. One of the prognostic factors causing cervical cancer death is clinical stage. The purpose of this research is to determine the probability of 3-year survival of cervical cancer patients based on the stage of cancer.

Methods : An analytical study with a retrospective cohort design using 274 medical records of cervical cancer patients for the period 2014-2016 in the Dr. Mohammad Hoesin Hospital in Palembang. Each patient's data was followed by its development for 3 years, starting from the time the patient was first diagnosed with cervical cancer and determined the stage of cancer (clinical staging).

Results : This study found that the probability of survival for 3 years for stage I was around $80 \%$, stage II was around $70 \%$, stage III was around $60 \%$, and stage IV was around $40 \%$. The median survival for stage IV is 24 months.
\end{abstract}

Conclusion : This research proves that the earlier the stage of cancer, the 3-year survival will increase.

Keywords: cervical cancer, stage, survival

\section{ABSTRAK}

Latar belakang : Kanker serviks merupakan penyakit keganasan sistem reproduksi paling umum dan banyak menyebabkan kematian pada wanita. Salah satu faktor prognostik penyebab kematian kanker serviks adalah stadium kanker. Tujuan penelitan ini adalah untuk mengetahui probabilitas ketahanan hidup 3 tahun pasien kanker serviks berdasarkan stadium kanker.

Metode : Studi analitik dengan desain kohort retrospektif dengan menggunakan 274 catatan rekam medis pasien kanker serviks periode tahun 2014-2016 di RSUP. Dr. Mohammad Hoesin Palembang. Masing- masing data pasien tersebut diikuti perkembangannya selama 3 tahun, dimulai sejak pasien pertama kali didiagnosis kanker serviks dan ditetapkan stadium kankernya (clinical staging).

Hasil : Penelitian ini mendapatkan bahwa probabilitas ketahanan hidup 3 tahun untuk stadium I sekitar $80 \%$, stadium II sekitar $70 \%$, stadium III sekitar $60 \%$, dan stadium IV sekitar $40 \%$. Median ketahanan hidup untuk stadium IV adalah 24 bulan.

Kesimpulan : Penelitian ini membuktikan bahwa semakin awal stadium kanker serviks maka ketahanan hidup 3 tahun akan semakin meningkat.

Kata Kunci : kanker serviks, stadium, ketahanan hidup 


\section{PENDAHULUAN}

Kanker serviks adalah salah satu penyakit dan penyebab kematian terbanyak pada wanita. Berdasarkan International Agency for Research on Cancer (IARC) tahun 2018 bahwa di Indonesia kanker serviks menempati urutan kedua jenis kanker terbanyak yang dialami wanita setelah kanker payudara dan sebagai urutan ketiga penyebab kematian akibat kanker setelah kanker paru dan kanker payudara(1). Berdasarkan Profil Kesehatan Sumatera Selatan bahwa penduduk yang menderita kanker serviks pada tahun 2015 sebanyak 797 orang atau sebanyak 55\% dari seluruh penduduk kriteria Penyakit Tidak Menular (PTM)(2).

Perkembangan penyakit kanker serviks berjalan secara perlahan, seringkali tidak menimbulkan gejala pada stadium awal, sehingga banyak wanita yang tidak menyadarinya jika telah menderita penyakit ini hingga saat wanita tersebut berobat ke rumah sakit dan dinyatakan sudah mengalami stadium akhir yang sulit diobati.

Menurut buku Panduan
Penatalaksanaan Kanker Serviks
Kementerian Kesehatan bahwa stadium
kanker serviks yang digunakan mengacu
pada International Federation of
Gynecology and Obstetrics (FIGO) yaitu terdapat 18 stadium; stadium 0 - stadium IVB. Diagnosis kanker serviks ditegakkan atas dasar anamnesa dan pemeriksaan fisik. Untuk penentuan stadium kanker serviks didasarkan atas pemeriksaan klinik(3).

Penentuan stadium klinik (clinical staging) adalah sangat penting karena merupakan salah satu pertimbangan dalam menentukan jenis pengobatan bagi pasien selain keadaan umum pasien dan sebagai indikator prognostik terbaik bagi kanker dalam mempengaruhi kematian dan ketahanan hidup pasien kanker serviks.

Untuk mengidentifikasi probabilitas ketahanan hidup, digunakan analisis survival dengan memodelkan faktorfaktor- faktor yang diduga berpengaruh terhadap ketahanan hidup. Beberapa penelitian baik di dalam negeri dan di luar negeri menyatakan bahwa stadium klinik merupakan faktor yang berpengaruh terhadap ketahanan hidup pasien kanker serviks, dengan meningkatnya stadium maka peluang untuk meninggal lebih besar. serta bahwa diagnosa dini dapat mengurangi resiko kematian dimana ketika penyakit kanker dilakukan tata laksana pada fase awal penyakit maka kanker dapat disembuhkan (4-6) Penelitian ini bertujuan untuk mengetahui probabilitas ketahanan hidup 3 tahun pasien kanker serviks berdasarkan masing- masing stadium klinik di RSUP. Dr. Mohammad Hoesin Palembang Tahun 2014-2016.

\section{METODE}

Penelitian ini merupakan studi analitik dengan desain kohort retrospektif. Jenis data yang dikumpukan adalah data yang berasal dari catatan rekam medis pasien kanker serviks di RSUP. Dr. Mohammad Hoesin Palembang dari periode 1 Januari 2014- 31 Desember 2016, dan masingmasing data pasien tersebut diikuti perkembangannya selama 3 tahun, dimulai 
sejak pasien pertama kali didiagnosis kanker serviks dan ditetapkan stadium klinik kankernya (clinical staging).

Kriteria inklusi penelitian ini adalah pasien kanker serviks yang telah dilakukan clinical staging, tercatat dalam register pasien dan memiliki catatan rekam medis yang lengkap atau tidak ada informasi informasi hilang.

Data dianalisis secara univariat dan bivariat. Stadium merupakan data kategorik, maka hasil analisis univariat akan ditampilkan dalam bentuk tabel distribusi frekuensi (prosentase), sedangkan lama waktu ketahanan hidup dinyatakan dalam bulan. Untuk mengukur probabilitas ketahanan hidup digunakan metode Kaplan Meier.

\section{HASIL}

Sampel keseluruhan pasien yang didiagnosa kanker serviks periode 20142016 yang memenuhi kriteria inklusi adalah sebanyak 274 pasien. Dari data diketahui bahwa sebanyak 52 subyek (18,98\%) mengalami event (meninggal) dan 222 subyek mengalami sensor (47 atau 17,15\% masih hidup, dan 175 atau 63,87\% loss to follow (hilang dari pengamatan).

Pada tabel 1 diketahui bahwa pasien berobat mulai dari kanker serviks stadium IA hingga IVB. Frekuensi terbanyak seusai tingkatan stadium didapatkan pada stadium I adalah stadium IB (7,3\%). Selanjutnya secara berurutan untuk tiap tingkatan stadium adalah stadium IIB, IIIB, dan IV A dengan frekuensi masing- masing 19,7\%;
$56,9 \%$, dan 2,2\%. Secara umum dapat disimpulkan bahwa sebagian besar pasien datang berobat ke rumah sakit adalah stadium IIIB, yaitu sebanyak $56,9 \%$.

\begin{tabular}{|c|c|c|}
\hline \multicolumn{3}{|c|}{ 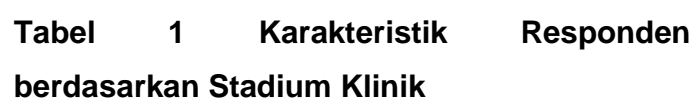 } \\
\hline Stadium & Jumlah & Prosentase (\%) \\
\hline $\mathrm{IA}$ & 1 & 0,4 \\
\hline IB & 20 & 7,3 \\
\hline IB1 & 6 & 2,2 \\
\hline IB2 & 11 & 4,0 \\
\hline IIA & 10 & 3,6 \\
\hline IIB & 54 & 19,7 \\
\hline IIIA & 5 & 1,8 \\
\hline IIIB & 156 & 56,9 \\
\hline IIIC & 1 & 0,4 \\
\hline IVA & 6 & 2,2 \\
\hline IVB & 4 & 1,5 \\
\hline
\end{tabular}

Bila dibuat secara lebih terperinci, pada stadium klinik I, frekuensi terbanyak adalah pada stadium IB (20/52,63\%). Pada stadium klinik II, frekuensi terbanyak adalah pada stadium IIB (54/ 84,4\%). Pada stadium III, frekuensi terbanyak adalah pada stadium IIIB 156/ 96,3\%). Pada stadium IV, frekuensi terbanyak adalah pada stadium IVA (6/60\%).

Stadium klinik juga dapat dikelompokkan menjadi stadium awal (stadium maksimal IIA) dan stadium akhir (stadium minimal IIB). Frekuensi terbanyak adalah pada stadium akhir (stadium IIBIVB) sebanyak 226 responden (82,48\%). 


\section{Gambar 1 Probabilitas Ketahanan Hidup Pasien Kanker Serviks}

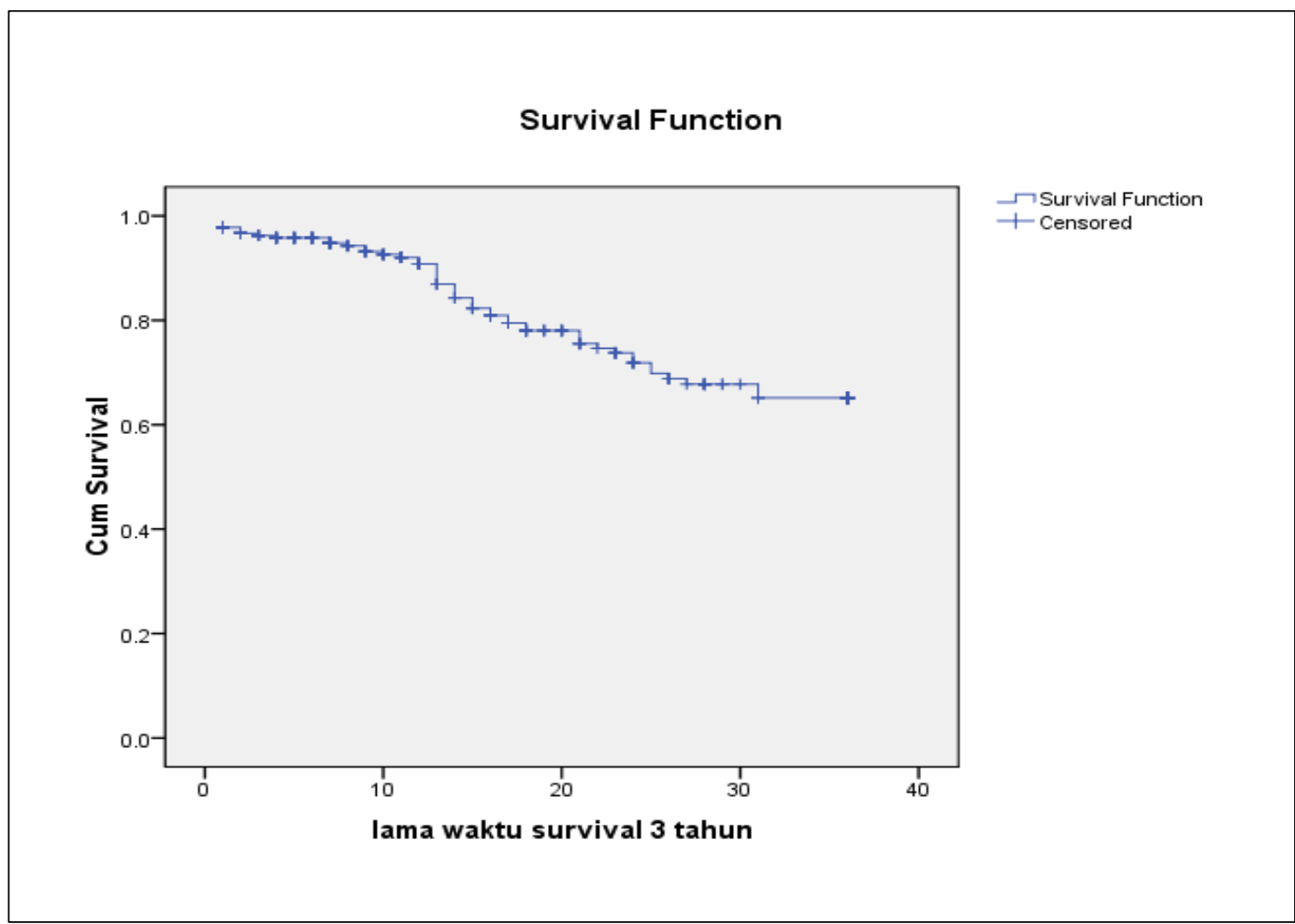

Berdasarkan kurva Kaplan Meier pada gambar 1 terlihat bahwa probabilitas ketahanan hidup pasien kanker serviks adalah sekitar 0,65 yang berarti bahwa sebanyak $65 \%$ pasien hingga akhir pengamatan selama 36 bulan tidak mengalami kematian (dapat hidup atau hilang dari pengamatan). Kurva menunjukkan penurunan kemampuan bertahan hidup mulai terjadi pada awal pengamatan bulan ke-1 sampai dengan bulan ke-30.

Gambar 2 Hubungan Stadium Klinik dengan Ketahanan Hidup 3 tahun

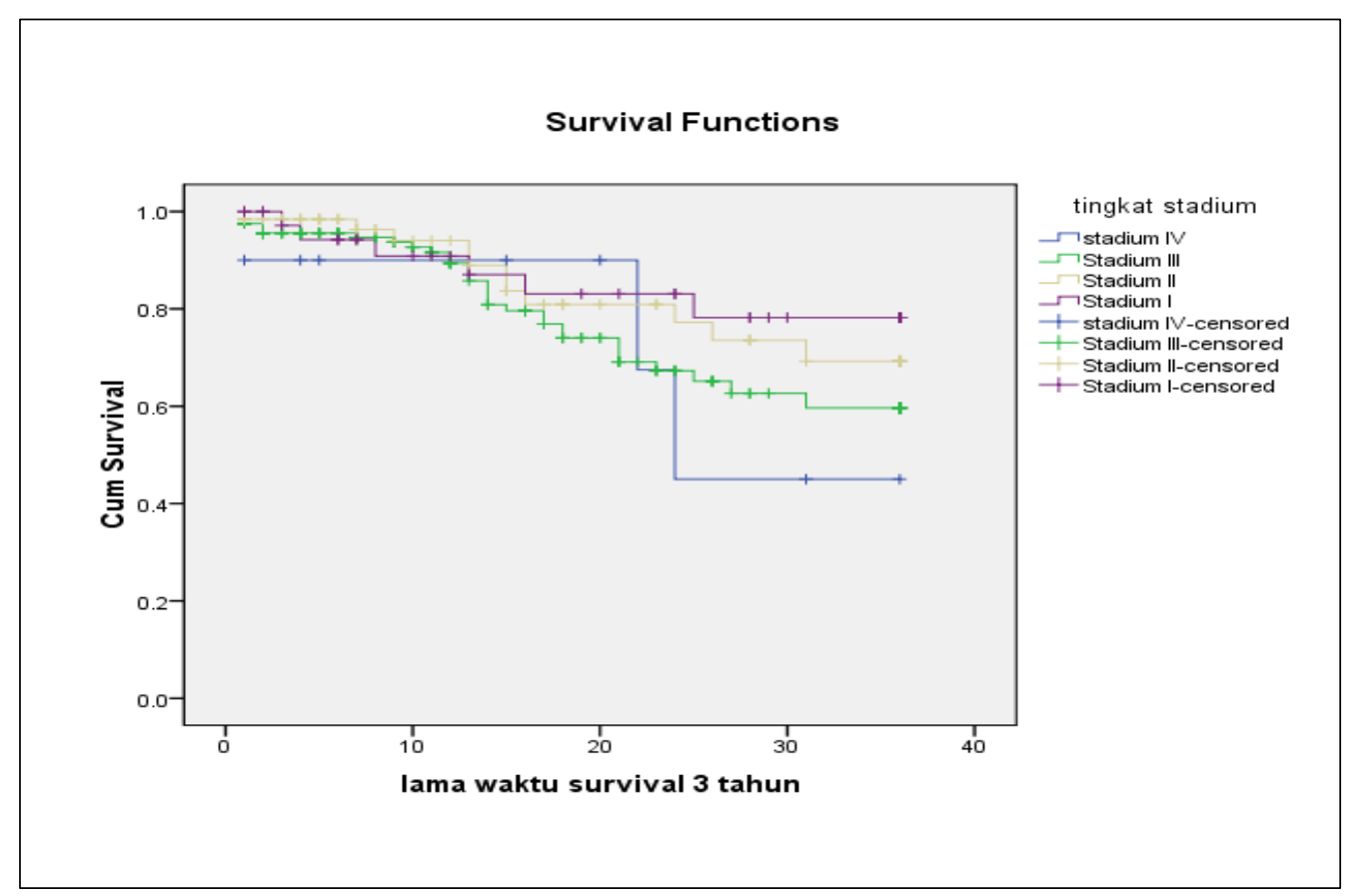


Berdasarkan kurva Kaplan Meier pada gambar 2 terlihat bahwa probabilitas ketahanan hidup pasien kanker serviks selama 36 bulan pengamatan pada kelompok stadium IV lebih rendah dibandingkan dengan kelompok stadium I, II, dan III. Lama waktu ketahanan hidup pasien kanker serviks menurun seiring dengan bertambahnya waktu, terlihat bahwa penurunan bermakna pada sekitar bulan ke-12, secara nyata terlihat pada stadium III. Probabilitas ketahanan hidup pasien kanker serviks penelitian ini pada kelompok stadium I sebesar sekitar 80\%, stadium II sekitar $70 \%$, stadium III sekitar $60 \%$, dan stadium IV sekitar $40 \%$.

Median ketahanan hidup pada kelompok stadium IV adalah 24 bulan, artinya adalah sebanyak $50 \%$ pasien telah meninggal dalam waktu 24 bulan. Sedangkan pada stadium I,II, dan III tidak ditemukan median ketahanan hidup, dimana probabilitas ketahanan hidup semuanya di atas 50\%.

\section{PEMBAHASAN}

Penelitian ini menunjukkan bahwa dari 274 pasien sebagai responden, sebanyak 18,98\% mengalami kematian; 17,15 \% hidup; dan 63,87\% hilang dari pengamatan. Bila dilihat dari besarnya jumlah pasien yang hilang dari pengamatan, jumlah ini lebih tinggi dibanding dengan penelitian di India dengan menggunakan data tahun 2006-2007, dilaporkan bahwa yang mengalami kematian $38,7 \%$; 48,1\% hidup; dan 13,2\% hilang dari pengamatan (6). Hal ini dapat menunjukkan bahwa pasien kanker serviks yang datang ke RSUP. Dr. Mohammad Hoesin Palembang tidak patuh kontrol atau berobat ulang. Kemungkinan lain adalah bahwa pendokumentasian rekam medis yang kurang lengkap, penyimpanan rekam medis yang tidak teratur sehingga beberapa status rekam medis pasien hilang, atau dapat juga bahwa sistem rekam medis yang tidak terorganisir secara baik dimana pasien yang datang berobat ulang menggunakan status rekam medis yang baru/ sistem rekam medis masih menggunakan sistem manual belum berdasarkan sistem rekam medis elektronik. Sedangkan bila dibandingkan dengan pasien kanker serviks di Malaysia tahun 2000-2005 dilaporkan 21,3\% meninggal dan yang hidup atau hilang dari pengamatan sebesar $78,3 \%(7)$

Hasil penelitian ini menunjukkan bahwa sebagian besar $(56,9 \%)$ yang berobat adalah pasien kanker serviks stadium IIIB, dan yang paling sedikit adalah stadium IA dan IIIC sebesar masing- masing 0,4\%. Dapat dikatakan juga bahwa yang berobat paling banyak adalah pasien kategori stadium akhir $(82,48 \%)$. Temuan sama dengan penelitian lain di Brazil dengan data pasien tahun 20002005 bahwa sebagian besar yang mengunjungi fasilitas kesehatan adalah pasien stadium III sebesar 43,98\% (8). Namun berbeda dengan penelitian lain dengan menggunakan data yang diambil tahun 20052010 yang melaporkan bahwa umumnya pasien berkunjung adalah kelompok pasien stadium IA-IB sebesar 69,3\% (5). Tingginya angka jumlah pasien stadium akhir atau rendahnya angka jumlah pasien stadium awal yang berkunjung ke pelayanan kesehatan menunjukkan bahwa pada umumnya kesadaran pasien untuk berobat masih rendah. Selain itu, kemungkinan karena penyakit kanker serviks jarang memberikan gejala-gejala yang mengganggu pada stadium awal, sehingga pasien kurang memperhatikan 
kondisinya. Sebaliknya dengan kondisi di luar negeri (Eropa), dimana kesadaran pasien untuk mencari pengobatan sudah lebih baik, ditunjang dengan fasilitas pemeriksaan diagnostik maupun fasilitas pelayanan kesehatan yang lebih maju.

Probabilitas ketahanan hidup pasien pada penelitian ini secara umum sekitar $65 \%$. Penelitian- penelitian lain diketahui bahwa probabilitas ketahahan hidup di Malaysia $71,1 \%$ (7), 57,4\% di Brazil tahun 2000-2005 (8), 84\% tahun 2005-2010 (5), 48,1\% di India (6), dan 43,8\% di Indonesia (9). Angka probabilitas ketahanan hidup di penelitian ini terlihat tinggi bila dibanding negara lain namun bila dicermati sebanyak 175 dari 274 pasien $(63,87 \%)$ responden penelitian ini adalah pasien yang hilang dalam pengamatan, yang kemungkinan pasien dapat hidup atau meninggal.

Pada penelitian ini didapatkan bahwa dengan semakin rendahnya stadium kanker serviks maka semakin tinggi lama probabilitas ketahanan hidup pasien, dengan kata lain stadium klinik berbanding terbalik dengan ketahanan hidup. Didapatkan bahwa probabilitas ketahanan hidup selama 36 bulan pengamatan untuk masing- masing stadium adalah stadium I sekitar $80 \%$, stadium II sekitar 70\%, stadium III sekitar $60 \%$ dan stadium IV sekitar 40\%. Median ketahanan hidup hanya pada stadium IV adalah 24 bulan.

Beberapa penelitian menyebutkan probabilitas ketahanan hidup pasien kanker serviks untuk stadium I sebesar $85 \%$, stadium II 64,3\%, stadium III 48,6\%, dan stadium IV sebesar $14 \%$ (8). Sedangkan di India, probabilitas ketahanan hidup stadium I sebesar $84 \%$, stadium IIA sebesar $80 \%$, stadium IIB sebesar $71,7 \%$, stadium IIIA sebesar $58,8 \%$, stadium IIIB sebesar $45,7 \%$, da stadium IV sebesar 8,1\% (6).

Secara teori, kanker serviks merupakan kanker yang paling berhasil diterapi bila terdeteksi dini. Kematian tinggi pada kanker serviks akibat keterlambatan diagnosis pada stadium akhir, keadaan umum yang lemah, status sosial ekonomi yang rendah, keterbatasan sumber daya, keterbatasan sarana dan prasarana, jenis histopatologi, dan derajat pendidikan ikut serta dalam menentukan prognosis dari penderita (10)..

Kanker serviks merupakan penyakit yang dapat dicegah, yaitu dengan vaksinasi HPV (Human Papillomavirus) dan beberapa macam metode skrining; Papnicolaou smears (Pap smear), tes HPV-DNA dan inspeksi visual. Diperkirakan dengan skrining kanker serviks dapat mencegah sekitar $70 \%$ kasus dibanding dengan tanpa skrining (11). Skrining dan deteksi dini memperbaiki outcome karena dengan semakin dininya perubahan sel terdeteksi, semakin tinggi kemungkinan ketahanan hidup pasien dan semakin besar kemungkinan dapat pulih ke keadaan yang normal, dan sebaliknya.

\section{KESIMPULAN DAN SARAN}

\section{Kesimpulan}

Penelitian ini menunjukkan bahwa dari pasien yang mengalami kematian sebanyak $18,98 \%$, hidup $17,5 \%$, dan hilang dari pengamatan $63,87 \%$. Pasien yang berobat sebagian besar adalah kelompok pasien stadium IIIB ( 56,9\%). Probabilitas ketahanan hidup 3 tahun secara umum sekitar $65 \%$. Semakin rendahnya stadium klinik pasien kanker serviks maka semakin tinggi probabilitas ketahanan hidup pasien, dengan kata lain stadium klinik berbanding terbalik 
dengan probabilitas ketahanan hidup. Secara

lebih rinci probabilitas ketahanan hidup untuk stadium I sekitar $80 \%$, stadium II sekitar $70 \%$, stadium III sekitar $60 \%$, dan stadium IV sekitar $40 \%$. Median ketahanan hidup untuk stadium IV adalah 24 bulan.
Bagi peneliti lain agar dapat meneliti faktor prognostik lain terhadap ketahanan hidup pasien kanker serviks.

\section{Saran}

Diharapkan setiap individu dapat meningkatkan kesadaran untuk deteksi dini, apabila ditemukan gejala atau tanda agar berobat ke pelayanan kesehatan dan mengikuti program penatalaksanaan secara teratur sesuai anjuran dokter,sehingga perkembangan penyakit dapat dikendalikan dan tercapai ketahanan hidup yang optimal.

\section{DAFTAR PUSTAKA}

1. WHO. Indonesia,Global Burden Cancer 2018 [Internet]. International Agency for Research on Cancer. 2018. p. 1. Available from: https://gco.iarc.fr/today/data/factsheets/populations/360-indonesia-factsheets.pdf

2. Sumsel D. Profil Kesehatan Sumatera Selatan Tahun 2015 [Internet]. 2016. 1-21 p. Available from: https://www.google.com/search?safe=strict\&sxsrf=ALeKk030bTN6NVNdQeXKTh-

NFgrWWj5KJQ\%3A1583679262890\&ei=HgdIXuD6NfLez7sPmemO6AE\&q=Profil+Kesehatan+provinsi+Su matera+Selatan+Tahun+2015.\&oq=Profil+Kesehatan+provinsi+Sumatera+Selatan+Tahun+2015.\&gs_l=psy -ab.3.

3. KEMENKES. Panduan Penatalaksanaan Kanker Serviks [Internet]. Komite Penanggulangan Kanker Nasional. 2016. 1-30 p. Available from: http://www.embase.com/search/results?subaction =viewrecord\&from=export\&id=L360287875\%5Cnhttp://www.ncbi.nIm.nih.gov/pubmed/22502670\%5Cnhttp: \%5Cnhttp://libcat.uinmalang.ac.id/index.php?p=show_detail\&id=13294\&keywords $=$ kanker

4. Afifah AN, Purnami SW. Uji Proportional Hazard pada Data Penderita Kanker Serviks di RSUD dr. Soetomo Surabaya. J Sains dan Seni ITS [Internet]. 2016;5(1):109-14. Available from: http://ejurnal.its.ac.id/index.php/sains_seni/article/view/14698

5. Carneiro SR, Fagundes M de A, Oliveira P de J, Tomazi LM, Souza G de silva, Nascimento M da C. FiveYear Survival and Associated Factors in Women Treated for Cervical Cancer at A Reference Hospital in The Brazilian Amazon. PLoS One [Internet]. 2017;12(11):1-11. Available from: https://journals.plos.org/plosone/article?id=10.1371/journal.pone.0187579

6. Vishma V, Prakash P, Kulkarni P, Renuka R. Survival and Prognostic factors for Cervical Cancer: A Hospital Based Study in Mysuru, India. Int J Community Med Public Heal [Internet]. 2015;3(1):218-23. Available from: https://www.ijcmph.com/index.php/ijcmph/article/view/679/577

7. Muhamad NA, Kamaluddin MA, Adon MY, Noh MA, Bakhtiar MF, Ibrahim Tamim NS, et al. Survival Rates of Cervical Cancer Patients in Malaysia. Asian Pacific J Cancer Prev. 2015;16(7):3067-72.

8. Mascarello KC, Zandonade E, Amorim MHC. Survival Analysis of Women with Cervical Cancer Treated at A Referral Hospital for Oncology in Espirito Santo State, Brazil, 2000-2005. Cad Saude Publica [Internet]. 2013;29(4):823-31. Available from: http://www.scielo.br/pdf/rsp/v45n4/2497.pdf

9. Hanni T, Wuryandari T. Model regresi Cox Proporsional Hazard pada Data ketahanan Hidup. Media Stat. 2013;6(1):11-20.

10. Rasjidi I. Epidemiologi Kanker Serviks. Indones J Cancer [Internet]. 2009;3(3):103-8. Available from: https://www.indonesianjournalofcancer.or.id/e-journal/index.php/ijoc/article/view/123

11. Howell-Jones R, Bailey A, Beddows S, Sargent A, De Silva N, Wilson G, et al. Multi-Site Study of HPV Type-Specific Prevalence in Women with Cervical Cancer, Intraepithelial Neoplasia and Normal Cytology, in England. $\mathrm{Br} \mathrm{J}$ Cancer [Internet]. 2010;103(2):209-16. Available from: https://www.ncbi.nlm.nih.gov/pmc/articles/PMC2906740/pdf/6605747a.pdf 